\title{
Reduction-melting extraction of trace elements from hazardous waste glass from an old glasswork's dump in the southeastern part of Sweden
}

\author{
Yahya Jani $^{1}$ (D) $\cdot$ William Hogland ${ }^{1}$
}

Received: 3 March 2017 / Accepted: 19 September 2017 / Published online: 24 September 2017

(C) The Author(s) 2017. This article is an open access publication

\begin{abstract}
At the southeastern part of Sweden, old art and crystal waste glass has been identified as a hazardous waste due to high weight concentrations of $\mathrm{Pb}(32.398 \%), \mathrm{Cd}$ $(0.085 \%)$, and As $(1.976 \%)$. The reduction-melting technique was used to investigate the extraction of these trace elements from powder waste glass of particle size $<1 \mathrm{~mm}$. Following a factorial design technique, the experimental results of the reduction-melting method showed that $99.9 \%$ of $\mathrm{Pb}, 100 \%$ of $\mathrm{Cd}$, and $99 \%$ of As could be extracted. For a batch of $10 \mathrm{~g}$ powder waste glass, the found experimental and theoretical optimum operating conditions were $1100{ }^{\circ} \mathrm{C}$ of melting temperature, $5 \mathrm{~g}$ of $\mathrm{Na}_{2} \mathrm{CO}_{3}, 2 \mathrm{~g}$ of carbon, and $120 \mathrm{~min}$ of melting time. The reduction-melting method displayed promising results which might help in recycling the extracted trace elements and glass compared to the current used solution of landfilling as hazardous wastes.
\end{abstract}

Keywords Crystal glass $\cdot$ Extraction of trace elements $\cdot$ Glass melting · Old glassworks dumps $\cdot$ Hazardous glass waste .

Reduction-melting method

Responsible editor: Philippe Garrigues

Yahya Jani

yahya.jani@lnu.se

1 Department of Biology and Environmental Science, Faculty of Health and Life Sciences, Linnaeus University (LNU), Landgången 3, SE-392 31 Kalmar, Sweden

\section{Introduction}

In Sweden, more than 24,500 contaminated sites have been identified by the SEPA in 2016 (Swedish Environmental Protection Agency) (SEPA 2016). One thousand sites from these were classified with the highest contamination risk (class 1) for the health and environment; the Swedish criteria are based on four risk classes with the highest as class 1 and the lowest class 4 (SEPA 2016). Among these, there were 34 old glassworks sites located in the top of the list (Kalmar County Administrative Board 2016). These glassworks are located in Småland region in the southeastern part of Sweden between Kalmar and Kronoberg counties where the famous "Kingdom of Crystal glass" is located. At these glassworks, extensive amounts of trace elements were used to produce different colors and types of glasses but mostly crystal and art glass with high weight contents of $\mathrm{Pb}$ (more than 32\%), As, $\mathrm{Cd}, \mathrm{Sb}, \mathrm{Cu}, \mathrm{Zn}$, and others (Hynes et al. 2004). According to Kalmar and Kronoberg county estimations, the total amount of waste glass at 25 of these glassworks was more than 500,000 $\mathrm{t}$ and with high contents of $\mathrm{Pb}$ (3100 t), As (420 t), and Cd (30 t) (Höglund et al. 2007), while the estimated total remediation cost of these 25 sites was more than 100 million $€$ based on the old excavating and landfilling method (Höglund et al. 2007).

The contamination of former and current glassworks with different trace elements has been also reported in other parts of the world (Pant and Singh 2014) such as the glassworks at Murano island in Italy (Rossini et al. 2010) and the glassworks sites at Firozabad town in the north central India (Varun et al. 2012). The reason behind the high concentrations of trace elements in waste glass was the uncontrolled consumption of these elements as raw material in the production process which leads to the contamination of most of these glassworks and their surroundings (Varun et al. 2012; Pant and Singh 
2014). Most importantly, the harmful healthy effects of these trace elements on the workers at glassworks and the people who are living around have been identified by different researchers (Apostoli et al. 1998; Pirastu et al. 1998; Rousseau et al. 2007; Sripaiboonkij et al. 2009; Brahmapurkar et al. 2013). These studies showed an increase in the frequency of lung, colon, larynx, brain, pharynx, stomach, and prostate cancers among the workers inside the glassworks and the people living close to these sites compared to the normal frequency in each country.

Unfortunately, there is a lack of information in literature about the extraction of trace elements from art and crystal waste glasses and the only proposed solution is the safe disposal in special landfills (Jani and Hogland 2014). However, landfilling waste glass means losing valuable resources that can be recycled back to the circular economy if methods of extracting trace elements from this waste can be found or developed. In the recent few years, different methods like mechano-chemical extraction (Zhang et al. 2013), enhanced leaching method (Barbieri et al. 2014; Bursi et al. 2015), volatilization process (Grause et al. 2014), vacuum metallurgical methods (Chen et al. 2009), and reduction-melting technique (Okada and Yonezawa 2013; Okada 2015; Mingfei et al. 2016) have been developed to extract $\mathrm{Pb}$ and other trace elements from CRT (cathode ray tube) glasses. Among these, the reduction-melting technique showed promising results of high recovery of $\mathrm{Pb}$ from CRT glasses with up to $99 \%$ (Mingfei et al. 2016).

The goal of the present study is to investigate the performance of the reduction-melting method to extract trace elements from waste art and crystal glasses dumped at an old glasswork site at the southeastern part of Sweden, the Pukeberg. Reducing the trace element content could be avoiding landfilling and also protecting human health and the environment. In addition, the reduction-melting process parameters were also studied statistically and experimentally to specify the optimum values that can give the highest percentage of recovery.

\section{Material and methods}

\section{Site description}

Pukeberg glasswork ( $56^{\circ} 43^{\prime} \mathrm{N}, 15^{\circ} 55^{\prime} \mathrm{E}$, Sweden) was built up and started production in 1871 in Nybro municipality in the southeastern part of Sweden. The glasswork is located about $1.5 \mathrm{~km}$ southeast of Nybro's municipality center, and the old glasswork's dump (where the sampling was done) is located to the south from the glasswork buildings. The main dump covers an area of approximately $15,000 \mathrm{~m}^{2}$ with a maximum depth of about $2.5 \mathrm{~m}$ (Elert and Höglund 2012), and it contains glass wastes of different colors and ages, chemical wastes containing trace elements, and other kinds of wastes from glass production process. Waste glass can be found on the ground surface, as shown in Fig. 1.

\section{Sampling}

The sampling points were chosen inside the Pukeberg main old dump (south of the glassworks buildings) where glass and other wastes from the daily production process were discarded between 1871 and 1950 (Höglund et al. 2007). Ten kilograms of waste glass was collected from five different points inside the main old dump and from different levels up to $50 \mathrm{~cm}$. The waste glass was washed with water few times, dried at room temperature $\left(25^{\circ} \mathrm{C}\right)$, and then stored in closed plastic bags during conducting and performing experiments and analyses.

\section{Experimental setup}

The waste glass was sorted and the colorless crystal glass was chosen to avoid the variation in the chemical composition of the different colors glass (Jani and Hogland 2014). Waste glass was then crushed and sieved to a particle size $<1 \mathrm{~mm}$ to produce a powder waste glass (PWG). This PWG was dried at $105{ }^{\circ} \mathrm{C}$ for $24 \mathrm{~h}$ and was used during all the reductionmelting experiments.

Ten grams of PWG was well mixed with specific weights (0-10 g) of reagent grades $\mathrm{Na}_{2} \mathrm{CO}_{3}$ (Sigma-Aldrich, USA) and (0-3 g) activated carbon (Sigma-Aldrich, USA). This mixture was then fed into a 50-ml high alumina crucible (Sigma-Aldrich, USA) which was placed later in an electrical furnace for a specific temperature $\left(900-1200^{\circ} \mathrm{C}\right)$ and heating time $(30-120 \mathrm{~min})$. The furnace temperature was raised according to a heating rate of $8^{\circ} \mathrm{C} / \mathrm{min}$. Finally and after passing the melting time, the sample was left to cool to room temperature. The produced glass and aggregated trace elements were separated by crushing the crucible and the produced glass, as shown in Fig. 7.

The reduction-melting experiments were done by following a factorial design technique by changing one parameter

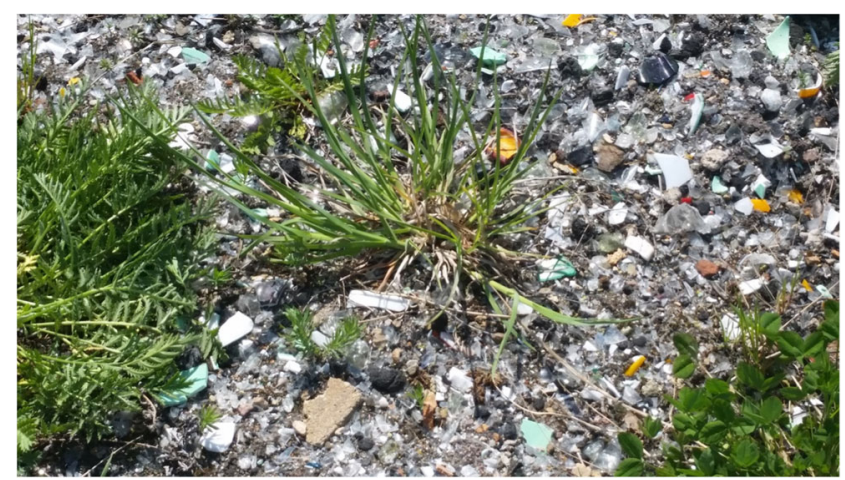

Fig. 1 Pukeberg glasswork dumpsite and the waste glass on the surface 
Table 1 The chemical composition of the sampled waste glass used in the present study (PWG) compared to the Swedish limits of hazardous waste (Avfall Sverige 2007)

\begin{tabular}{lll}
\hline $\begin{array}{l}\text { Element } \\
(\mathrm{mg} / \mathrm{kg})\end{array}$ & $\begin{array}{l}\text { Mean value of the PWG, } \\
\text { present study }\end{array}$ & $\begin{array}{l}\text { Swedish limits of hazardous wastes } \\
\text { (Avfall Sverige 2007) }\end{array}$ \\
\hline $\mathrm{Si}$ & $438,241(3547)$ & \\
$\mathrm{S}$ & $132,508(2896)$ & \\
$\mathrm{Cl}$ & $12,202(422)$ & 1000 \\
$\mathrm{~K}$ & $52,494(825)$ & \\
$\mathrm{Cr}$ & $54(7)$ & \\
$\mathrm{Ca}$ & $4294(148)$ & 2500 \\
$\mathrm{Mn}$ & $137(7)$ & 2500 \\
$\mathrm{Fe}$ & $538(111)$ & 1000 \\
$\mathrm{Cu}$ & $856(69)$ & 10,000 \\
$\mathrm{Zn}$ & $1616(106)$ & 100 \\
$\mathrm{As}$ & $19,761(705)$ & 10,000 \\
$\mathrm{Mo}$ & $44(5)$ & 10,000 \\
$\mathrm{Cd}$ & $847(38)$ & 2500 \\
$\mathrm{Sn}$ & $581(44)$ & \\
$\mathrm{Sb}$ & $4373(108)$ & $878(30)$ \\
$\mathrm{Ba}$ & $323,977(8524)$ & \\
$\mathrm{Pb}$ & & \\
\hline
\end{tabular}

Note: values between brackets represent the standard deviation. And the red color means that the found value was higher than that of the Swedish limits of hazardous waste each time from the four studied parameters: melting temperature $\left(900-1200{ }^{\circ} \mathrm{C}\right)$, weight of $\mathrm{Na}_{2} \mathrm{CO}_{3}(0-10 \mathrm{~g})$, weight of carbon (0-3 g), and melting time (30-120 $\mathrm{min})$. However, the reduction-melting experiment was considered successful only in case when the participating trace elements could be seen with the naked eyes in the final products.

\section{Analyses}

A semi-quantitative X-ray fluorescence analysis (XRF), Olympus DS-4000 (Innov-X system, USA), was used to find the chemical composition of the PWG and the produced glass and trace elements after each experiment.

The following equation was used to calculate the recovery percentage of the trace elements (Okada et al. 2012; Okada 2015):

\section{Trace element recovery\%}

$$
=\left(1-\frac{\frac{\text { final concentration of trace element }}{\text { final concentration of silica }}}{\frac{\text { initial concentration of trace element }}{\text { initial concentration of silica }}}\right) \times 100
$$

where final concentrations of trace element and silica are the concentrations after each reduction-melting experiment, while the initial concentration means the concentration in the PWG. The purpose behind using this equation is to eliminate the dilution effects of the $\mathrm{Na}_{2} \mathrm{CO}_{3}$ on the trace elements.

\section{Leaching test}

The reduction-melting glass residuals at the optimum conditions were crushed and sieved to particle sizes of less than $2 \mathrm{~mm}$. The leachate was prepared by mixing $5 \mathrm{~g}$ of glass with $50 \mathrm{ml}$ distilled water in one stage shaking leaching test (liquid to solid ratio (L/S) of 10$)$ for $24 \mathrm{~h}$ by following the Nordtest method NT ENVIR 004. Then, the leachate was analyzed by ICP-MS to find the trace elements content according to the EN 12457-3 standard.

\section{Results and discussions}

\section{Chemical composition}

The chemical composition of the PWG compared to the Swedish limits (Avfall Sverige 2007) of hazardous wastes is shown in Table 1. The results showed that the PWG was identified as hazardous waste due to the high concentrations of $\mathrm{Pb}, \mathrm{Cd}$, and As. However, high concentrations of $\mathrm{Sb}, \mathrm{Cu}$, and $\mathrm{Zn}$ were also found but with concentrations less than that of the Swedish guidelines. For the safe recycling or even landfilling of Pukeberg waste glass as inert material, the concentrations of $\mathrm{Pb}, \mathrm{Cd}$, and $\mathrm{As}$ must be reduced by extracting these trace elements to accepted levels.

On the other hand, the comparison between the chemical composition of PWG and CRT glass (Mear et al. 2006) is 
Table 2 PWG glass chemical composition compared to CRT glass based on weight percentage

\begin{tabular}{llc}
\hline $\begin{array}{l}\text { Element } \\
(\text { wt } \%)\end{array}$ & $\begin{array}{l}\text { Mean value of the PWG, } \\
\text { present study }\end{array}$ & $\begin{array}{l}\text { Mean value of CRT glass } \\
\text { (Mear et al. 2006) }\end{array}$ \\
\hline $\mathrm{Si}$ & 43.82 & 49.77 \\
$\mathrm{~S}$ & 13.25 & \\
$\mathrm{Cl}$ & 1.22 & 7.31 \\
$\mathrm{~K}$ & 5.25 & \\
$\mathrm{Cr}$ & 0.01 & 3.56 \\
$\mathrm{Ca}$ & 0.43 & \\
$\mathrm{Mn}$ & 0.01 & 0.1 \\
$\mathrm{Fe}$ & 0.05 & 0.03 \\
$\mathrm{Cu}$ & 0.09 & 0.01 \\
$\mathrm{Zn}$ & 0.16 & \\
$\mathrm{As}$ & 1.98 & \\
$\mathrm{Mo}$ & 0.01 & \\
$\mathrm{Cd}$ & 0.08 & 0.57 \\
$\mathrm{Sn}$ & 0.06 & 0.36 \\
$\mathrm{Sb}$ & 0.44 & 22.90 \\
$\mathrm{Ba}$ & 0.09 & 3.28 \\
$\mathrm{~Pb}$ & 32.40 & 12.11 \\
$\mathrm{Al}$ & 0.65 & \\
$\mathrm{Others}$ & & \\
\hline
\end{tabular}

shown in Table 2. The concentrations of $\mathrm{Pb}, \mathrm{As}$, and $\mathrm{Zn}$ were higher in PWG compared to CRT glass. In reverse, the concentrations of $\mathrm{Si}, \mathrm{K}, \mathrm{Ca}, \mathrm{Fe}, \mathrm{Sb}$, and $\mathrm{Ba}$ were slightly higher in CRT glass. Some trace elements like $\mathrm{Cr}$ and $\mathrm{Cu}$ appear only in PWG while others like Al appear only in CRT glass. In general, CRT and crystal glasses are known as lead glasses because the chemical composition is dominated by $\mathrm{Pb}$ (BREF 2009). Hence, methods used to extract trace elements from CRT glass could be also used for crystal glass due to the similarity in the chemical and physical properties (Vogel 1994; Shelby 2005; BREF 2009).

\section{Effect of the reduction-melting parameters on the trace elements recovery}

According to different studies (Okada and Yonezawa 2013; Okada 2015; Mingfei et al. 2016), the reduction-melting method depends on four parameters that plays vital role in the extraction of trace elements from CRT glasses. These parameters are the melting temperature, $\mathrm{Na}_{2} \mathrm{CO}_{3}$ weight, carbon dosage, and melting time. However, to investigate the effect of these parameters on the percentage of recovery of $\mathrm{Pb}, \mathrm{Cd}$, and As and to find the optimum values with the highest recovery, these parameters were studied experimentally and theoretically as follows.

\section{Melting temperature}

Due to the homogenous chemical structure of glass and the strong bonded of silicon oxide to the trace elements oxides, high temperature, higher than $900{ }^{\circ} \mathrm{C}$, was needed for the melting of glass and releasing the trace elements from the glass network structure (Singh et al. 2016). However, this was enhanced by the addition of $\mathrm{Na}_{2} \mathrm{CO}_{3}$ and carbon, as will be discussed later. Figure 2 shows the effect of melting temperature on the percentage of recovery of $\mathrm{Pb}, \mathrm{Cd}$, and $\mathrm{As}$. The results showed that increasing the temperature increased the recovery of the three trace elements linearly up to $1100{ }^{\circ} \mathrm{C}$.

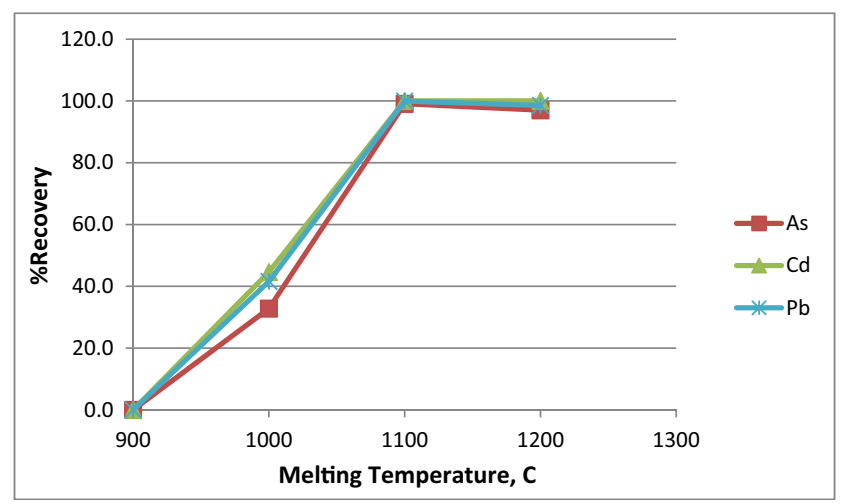

Fig. 2 The effect of melting temperature on the percentage recovery of $\mathrm{Pb}, \mathrm{Cd}$, and As from the studied PWG 


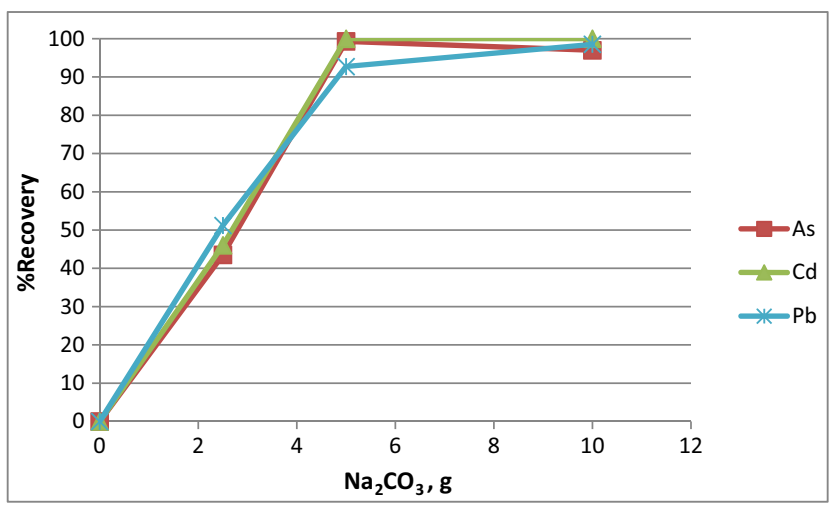

Fig. 3 The effect of $\mathrm{Na}_{2} \mathrm{CO}_{3}$ weight on the percentage of recovery of $\mathrm{Pb}$, $\mathrm{Cd}$, and As from the studied PWG

According to Stokes' law, the separation efficiency of the metallic trace elements depends on the sedimentation velocity which in turn depends on the following:

$V=\frac{\left(\rho_{\mathrm{s}}-\rho\right) g d_{\mathrm{s}}^{2}}{18 \mu}$

where $V$ is the sedimentation velocity of the metallic trace elements' particle, $\rho_{\mathrm{s}}$ and $\rho$ are the densities of metallic trace element and glass, respectively, $g$ is the gravitational acceleration, $d_{\mathrm{s}}$ is the particle diameter of the metallic trace elements, and $\mu$ is the glass viscosity. The density difference $\left(\rho_{\mathrm{s}}-\rho\right)$ between the metallic trace elements $\mathrm{Pb}\left(11.3 \mathrm{~g} \mathrm{~cm}^{-3}\right), \mathrm{Cd}$ $\left(8.7 \mathrm{~g} \mathrm{~cm}^{-3}\right)$, and As $\left(5.7 \mathrm{~g} \mathrm{~cm}^{-3}\right)$ and glass $\left(3 \mathrm{~g} \mathrm{~cm}^{-3}\right)$ (Green and Perry 2007) is acting as the driving force to accelerate the sedimentation velocity. Moreover, the sedimentation velocity increased by decreasing glass viscosity due to the high temperature and the addition of $\mathrm{Na}_{2} \mathrm{CO}_{3}$ that modify the network structure of glass by breaking the $\mathrm{SiO}_{2}$ and releasing the mobile $\mathrm{SiO}_{4}$ (Vogel 1994).

At $900{ }^{\circ} \mathrm{C}$, no aggregates of trace elements were noticed with the naked eyes in the final products of the melting experiments and the percentage of recovery was considered zero. In addition, the recovery results at 1100 and $1200^{\circ} \mathrm{C}$ were almost the same for the three trace elements which means that studying the melting temperature further at temperatures higher than $1200{ }^{\circ} \mathrm{C}$ was not relevant. The highest percentage of recovery of $\mathrm{Pb}(99.9 \%), \mathrm{Cd}(100 \%)$, and $\mathrm{As}(99 \%)$ was found at $1100{ }^{\circ} \mathrm{C}$; this result was in agreement with that of $\mathrm{Li}$ et al. (2012) and Okada et al. (2012) for the recovery of Pb from CRT glass.

\section{Addition of $\mathrm{Na}_{2} \mathrm{CO}_{3}$}

The effect of the addition of $\mathrm{Na}_{2} \mathrm{CO}_{3}$ (flux) on the recovery percentage of $\mathrm{Pb}, \mathrm{Cd}$, and As is shown in Fig. 3. The percentage of recovery of the three trace elements increased with increasing the $\mathrm{Na}_{2} \mathrm{CO}_{3}$ weight up to $5 \mathrm{~g}$ for each $10 \mathrm{~g}$ of
PWG. Then, increasing the $\mathrm{Na}_{2} \mathrm{CO}_{3}$ further did not affect the percentage of recovery. At temperatures higher than $600{ }^{\circ} \mathrm{C}$, the $\mathrm{Na}_{2} \mathrm{CO}_{3}$ will be dissociated to $\mathrm{CO}_{2}$ and $\mathrm{Na}_{2} \mathrm{O}$, shown in the chemical reaction 1 , which acts as a glass network modifier (Mingfei et al. 2016):

$\mathrm{Na}_{2} \mathrm{CO}_{3}=\mathrm{Na}_{2} \mathrm{O}+\mathrm{CO}_{2}$

As can be shown in the chemical reactions $2-4$, the $\mathrm{Na}_{2} \mathrm{O}$ will replace the $\mathrm{PbO}$ in the $\mathrm{PbO}-\mathrm{SiO}_{2}$ structure due to the higher strength of the $\mathrm{Na}-\mathrm{O}$ bond compared to that of the $\mathrm{Pb}-\mathrm{O}$ resulting in decreasing the molten glass viscosity and promoting the trace elements precipitation ( $\mathrm{Li}$ et al. 2012). Additionally, the produced $\mathrm{CO}_{2}$ (with the help of the added carbon) will reduce the $\mathrm{PbO}$ to produce metallic lead at temperature higher than $900{ }^{\circ} \mathrm{C}$ and the reduction rate increased quickly with increasing the temperature (Xing and Zhang 2011).

$\mathrm{Na}_{2} \mathrm{O}+\mathrm{PbO}-\mathrm{nSiO}_{2}=\mathrm{Na}_{2} \mathrm{O}-n \mathrm{SiO}_{2}+\mathrm{PbO}$

$\mathrm{C}+\mathrm{CO}_{2}=2 \mathrm{CO}$

$\mathrm{PbO}+\mathrm{CO}=\mathrm{Pb}+\mathrm{CO}_{2}$

Moreover, the same mechanism will also enhance the reduction of $\mathrm{Cd}$ and As oxides ( $\mathrm{Li}$ et al. 2012). The same results were also found by Li et al. (2012) and Okada and Yonezawa (2013) but for the CRT glass.

\section{Carbon addition}

Carbon is considered as one of the best and most used reducing agents in metallurgy processes like in the production of steal (Mingfei et al. 2016). The carbon itself and the CO has the ability to reduce trace elements oxides to metallic form like in the case of $\mathrm{Pb}, \mathrm{Cd}$, and As according to the chemical reactions (4) and (5):

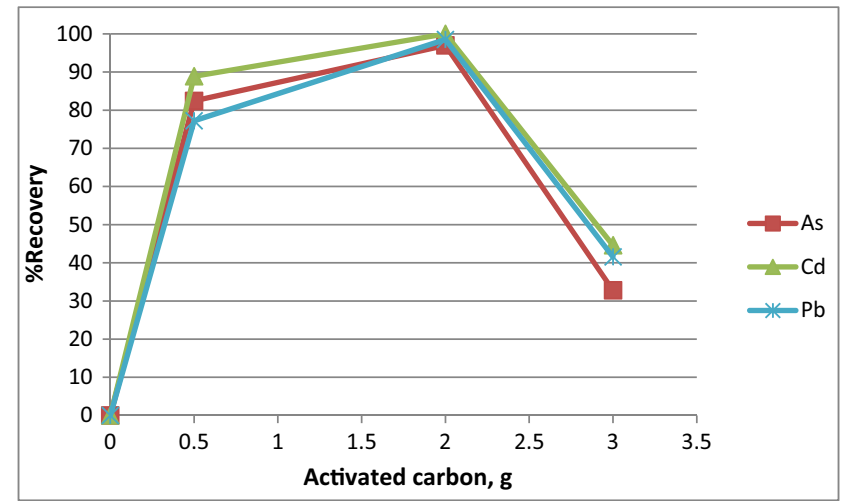

Fig. 4 The effects of carbon dosage on the recovery rate of $\mathrm{Pb}, \mathrm{Cd}$, and As from PWG 


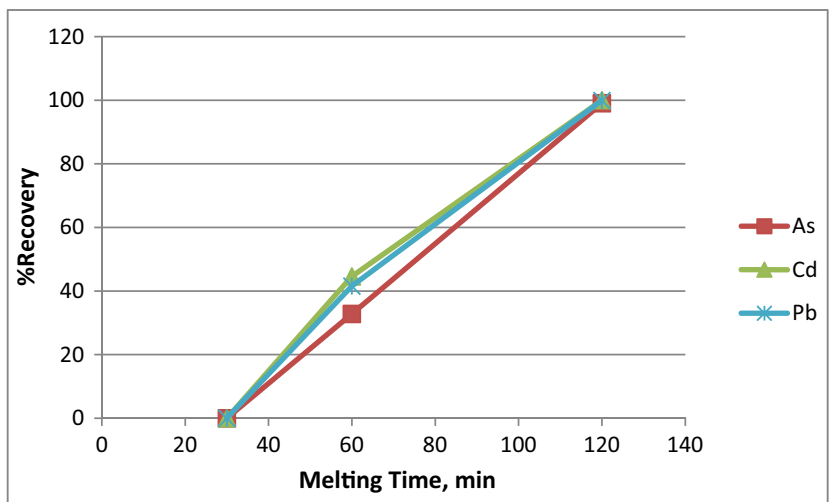

Fig. 5 The effect of melting time of the percentage of recovery of $\mathrm{Pb}, \mathrm{Cd}$, and As from PWG

$2 \mathrm{MO}+2 \mathrm{CO}=2 \mathrm{M}+2 \mathrm{CO}_{2}$

where $\mathrm{M}$ means trace element and MO trace element oxide. As shown in Fig. 4, the percentage of trace elements recovery increased with increasing the carbon weight till reaching the maximum recovery at $2 \mathrm{~g}$ of carbon for each $10 \mathrm{~g}$ of PWG then the recovery rate decreased with increasing the weight of carbon further. This might be due to the incomplete burning of carbon as was noticed in the final product of the $3 \mathrm{~g}$ experiment. The same result was also found by Okada et al. (2012) for CRT glass.

\section{Melting time}

Figure 5 shows the effect of melting time on the percentage of recovery of $\mathrm{Pb}, \mathrm{Cd}$, and As from PWG. The results showed that the recovery increased linearly with increasing the melting time reaching the maximum recovery of $\mathrm{Pb}(99.9 \%), \mathrm{Cd}$ $(100 \%)$, and As (99\%) at $120 \mathrm{~min}$. Okada and Yonezawa (2013) showed that the percentage of recovery was controlled by the reduction rate of trace elements oxides; it means that when the time increases, further the percentage of recovery decreased due to the reduction in the concentrations of the trace elements oxides (Okada and Yonezawa 2013). In addition, the size of the precipitating trace elements particle $\left(d^{2}{ }_{\mathrm{s}}\right)$ increased with increasing the melting time as was noticed between the particles sizes at 60- and 120-min experiments. This could also enhance the separation efficiency of the trace elements due to the acceleration in the sedimentation velocity that was explained earlier by the Stokes' law.

\section{Statistical analyses}

A theoretical polynomial model was used to find the correlation between the reduction-melting process parameters and their effects on the percentage recovery of the studied trace elements $\mathrm{Pb}, \mathrm{Cd}$, and As. However, the same model was used to find the theoretical optimum values of the studied parameters and compared them with the experimental results by finding the correlation coefficient for each trace element. The used polynomial model was as follows:

$$
\begin{aligned}
Y= & a_{0}+a_{1} X_{1}+a_{2} X_{2}+a_{3} X_{3}+a_{4} X_{4}+a_{5} X_{1}^{2}+a_{6} X_{2}^{2} \\
& +a_{7} X_{3}^{2}+a_{8} X_{4}^{2}+a_{9} X_{1} X_{2} X_{3} X_{4}
\end{aligned}
$$

where $Y$ is the percentage of recovery, $X_{1}$ is the melting temperature in degree Celsius, $X_{2}$ is the carbon weight in grams, $X_{3}$ is the $\mathrm{Na}_{2} \mathrm{CO}_{3}$ weight in grams, $X_{4}$ is the melting time in minutes, and the $a_{(0-9)}$ is the model constants. To find the model constants and the correlation coefficients for the recovery percentage of each trace element, a STATISTICA program version 6 was used. As shown in Table 3, high correlation coefficients were found for the recovery of the three trace elements according to the proposed model equation with 99.2, 99.1, and 98.6\% for $\mathrm{Pb}, \mathrm{Cd}$, and As, respectively. This means that these parameters are highly interconnected and they are playing vital role in the recovery of the trace elements from the studied waste glass. In addition, the statistical results (using least square method) showed that the experimental and theoretical optimum values of the four parameters were the same with melting temperature of $1100^{\circ} \mathrm{C}, 2 \mathrm{~g}$ of carbon, $5 \mathrm{~g}$ of $\mathrm{Na}_{2} \mathrm{CO}_{3}$, and for $120 \mathrm{~min}$ of melting time, as shown in

\begin{tabular}{|c|c|c|}
\hline $\begin{array}{l}\text { Trace } \\
\text { element }\end{array}$ & Model equation & $\begin{array}{l}\text { Correlation } \\
\text { coefficient } \\
(\%)\end{array}$ \\
\hline $\mathrm{Pb}$ & $Y=-1404.25+1.77 X_{1}+85.68 X_{2}+24.23 X_{3}+4.99 X_{4}+0.0007 X_{1}^{2}-20.22 X_{2}^{2}-1.14 X_{3}^{2}-0.03 X_{4}^{2}-0.00001 X_{1} X_{2} X_{3} X_{4}$ & 99.2 \\
\hline $\mathrm{Cd}$ & $Y=-1348.28+1.74 X_{1}+62.2 X_{2}+25.54 X_{3}+4.4 X_{4}+0.0006 X_{1}^{2}-15.51 X_{2}^{2}-1.35 X_{3}^{2}-0.02 X_{4}^{2}-0.00007 X_{1} X_{2} X_{3} X_{4}$ & 99.1 \\
\hline As & $Y=-1205.09+1.42 X_{1}+73.07 X_{2}+24.02 X_{3}+4.96 X_{4}+0.0005 X_{1}^{2}-18.35 X_{2}^{2}-1.23 X_{3}^{2}-0.03 X_{4}^{2}-0.00008 X_{1} X_{2} X_{3} X_{4}$ & 98.6 \\
\hline
\end{tabular}

Table 3 The polynomial model equations of the percentage of recovery of $\mathrm{Pb}, \mathrm{Cd}$, and As from the studied PWG with the correlation confidents 


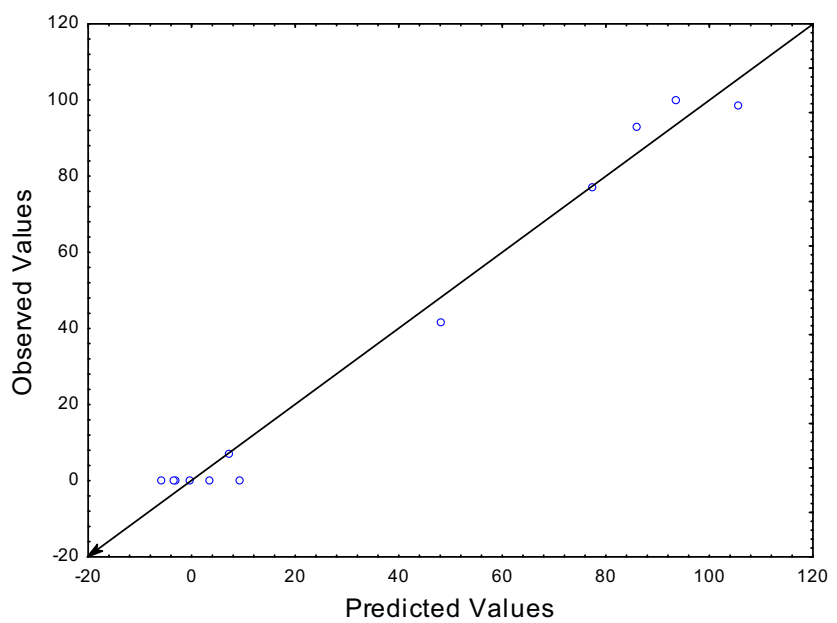

(a) Lead Recovery $\%$

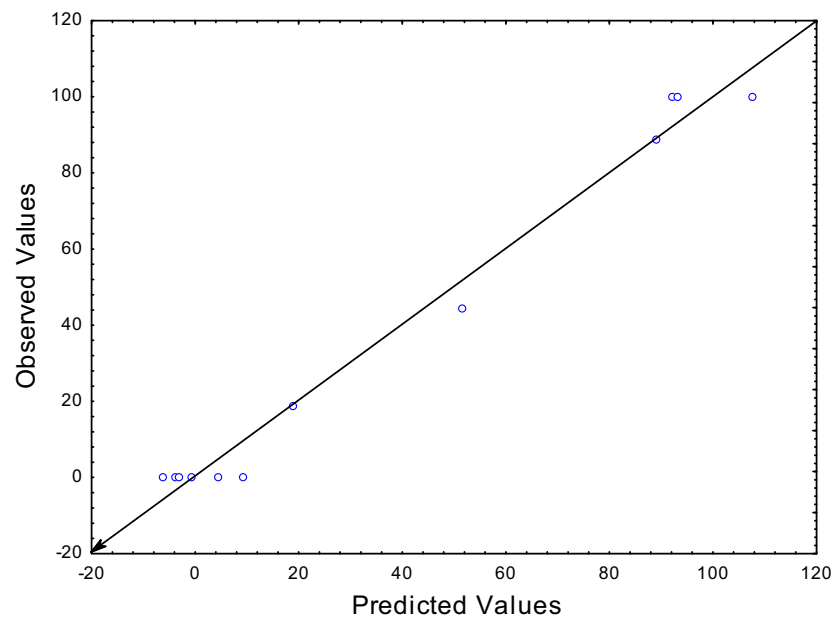

(b) Cadmium Recovery \%

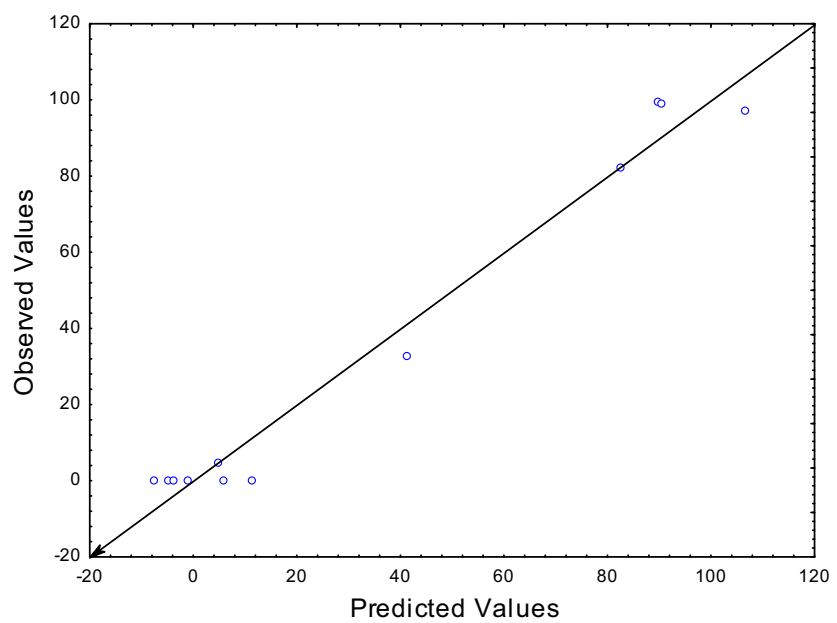

(c) Arsenic Recovery \%

Fig. 6 The observed (experimental) versus the predicted (theoretical calculation) values of the percentage recovery of $\mathbf{a}$ lead, $\mathbf{b}$ cadmium, and $\mathbf{c}$ arsenic

Fig. 6. These optimum values gave the highest percentage of recovery of $\mathrm{Pb}(99.9 \%), \mathrm{Cd}(100 \%)$, and $\mathrm{As}(99 \%)$, with the final result shown in Fig. 7.

\section{Leachate trace element content}

The leachate trace element content of the residual glass at the optimum operating conditions compared to the European landfill guidelines (European Union 2003) for inert and hazardous waste is shown in Table 4. The results showed that the reduction-melting method could reduce the concentrations of all the trace elements, but still, the concentrations were higher than the European guidelines of landfilling as inert and the As and $\mathrm{Sb}$ concentrations were double and triple higher than the European guidelines of landfilling as hazardous wastes. This could be due to the mobilization of the trace elements in the glass network structure after the reduction-melting experiments (Okada et al. 2012). To stabilize these elements in the glass network structure and reducing the leaching effects, the residual glass was re-melted at $1200{ }^{\circ} \mathrm{C}$ for $1 \mathrm{~h}$ and the leaching test was repeated after crushing the glass residual to particle sizes less than $2 \mathrm{~mm}$. The results, shown in Table 4 , indicated that the re-melting could reduce the leaching of all the trace elements to levels less than that of the European guidelines of landfilling as inert waste (European Union 2003). This could be explained by the oxidation of the metallic trace elements which leads to the re-connection of these oxides back in the $\mathrm{SiO}_{2}$ glass network structure as was also noticed by Okada et al. (2012). However, more experimental work is needed in future to explore the re-melting stability performance.

\section{Trace element mass balance}

At high operating temperature $\left(900-1200^{\circ} \mathrm{C}\right)$, there is a probability for the evaporation of some trace elements. Therefore, the mass balance of the trace element content of the PWG, the glass residual, and the separated trace elements (shown in Table 5) was analyzed. The found differences were less than $2 \%$ and within the XRF experimental analyses errors (Okada 2015).

\section{Recycling potential}

Reducing the trace element content of the Swedish art and crystal waste glasses can enhance the recycling of both the extracted trace elements and the remaining glass. Recycling these waste materials, which were considered as hazardous due to the high weight concentrations of $\mathrm{Pb}, \mathrm{Cd}$, and $\mathrm{As}$, is important for protecting human health and the environmental and for the sustainability of the Earth natural resources that have been used extensively in glass industry (Jani and Hogland 2014). Furthermore, the European circular economy goals emphasized on considering all the waste materials, like wastes glass, as valuable resources that must be recovered and recycled back. The reduction-melting process showed promising results in minimizing the hazardous trace elements in the 
Fig. 7 The final product of the reduction-melting experiment at the optimum values of the studied parameters $1100^{\circ} \mathrm{C}$ of temperature, $2 \mathrm{~g}$ of carbon, $5 \mathrm{~g}$ of $\mathrm{Na}_{2} \mathrm{CO}_{3}$, and 120 min of melting time. a Before crushing and separating. b After crushing
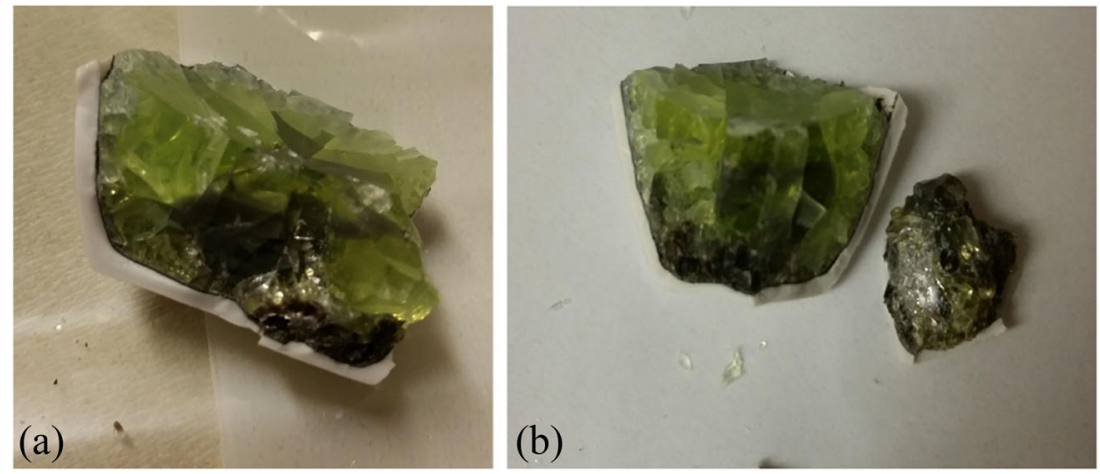

studied waste glass which might help in using these glasses as raw material in the production of new crystal and art glass, in cement and construction industry (Jani and Hogland 2014), glass ceramics (Kritikaki et al. 2016), or even in the production of foam glass (Guo et al. 2010).

On the other hand, the extracted trace elements $(\mathrm{Pb}, \mathrm{Cd}$, and As) can be also recycled like in battery industry especially the lead, due to the high weight content (32.398\%). Methods like electrochemical, supercritical, and vacuum metallurgical technologies have been used for the purification of trace elements like lead (Zhang and Xu 2016). However, recycling the extracted trace elements and glass must be studied carefully in future in order to specify the safe use and the requirements of the raw materials of the target industries.

\section{Conclusions}

The Kingdom of Crystal glass in the southeastern part of Sweden is well known by the production of the famous

Table 4 Leachate trace elements content of residual glass at the reduction-melting optimum conditions compared to the European Union guidelines (European Union 2003) of landfilling as inert and hazardous wastes at liquid to solid ratio of 10

\begin{tabular}{lllll}
\hline $\begin{array}{l}\text { Element } \\
(\mathrm{mg} / \mathrm{kg})\end{array}$ & $\begin{array}{l}\text { Mean value } \\
\text { of residual } \\
\text { glass before } \\
\text { re-melting, } \\
\text { present study }\end{array}$ & $\begin{array}{l}\text { Mean value } \\
\text { of residual } \\
\text { glass after re- } \\
\text { melting, } \\
\text { present study }\end{array}$ & $\begin{array}{l}\text { Limits of } \\
\text { landfilling as } \\
\text { (European } \\
\text { Union 2003) }\end{array}$ & $\begin{array}{l}\text { Limits of } \\
\text { landfilling as } \\
\text { hazardous } \\
\text { waste } \\
\text { (European } \\
\text { Union 2003) }\end{array}$ \\
\hline $\mathrm{Cr}$ & 0 & 0 & 10 & 70 \\
$\mathrm{Mn}$ & 0 & 0 & - & - \\
$\mathrm{Cu}$ & 0 & 0 & 50 & 100 \\
$\mathrm{Zn}$ & 0.3 & 0.01 & 50 & 200 \\
$\mathrm{As}$ & 45.8 & 0.07 & 2 & 25 \\
$\mathrm{Cd}$ & 0 & 0 & 1 & 5 \\
$\mathrm{Sb}$ & 15.6 & 0.06 & 0.7 & 5 \\
$\mathrm{Ba}$ & 0.2 & 0 & 100 & 300 \\
$\mathrm{~Pb}$ & 49 & 0.01 & 10 & 50 \\
\hline
\end{tabular}

art and crystal glass. The uncontrolled consumption of trace elements as raw materials in the production process leads to hazardous contamination of these glasses with high weight concentrations of $\mathrm{Pb}(32.398 \%), \mathrm{Cd}$ $(0.085 \%)$, and As $(1.976 \%)$. The reduction-melting method was used to extract these trace elements from sampled waste glass from the dumpsite at Pukeberg glasswork. The experimental results of the followed factorial design of experiments showed that the percentage of recovery of the trace elements increased with increasing melting temperature, $\mathrm{Na}_{2} \mathrm{CO}_{3}$, carbon, and melting time. In addition, the experimental and theoretical results displayed that these four parameters were highly interconnected and played vital role in the reduction-melting process. The optimum melting temperature $\left(1100{ }^{\circ} \mathrm{C}\right), \mathrm{Na}_{2} \mathrm{CO}_{3}$ weight $(5 \mathrm{~g})$, carbon (2 g), and melting time (120 $\mathrm{min})$ were found experimentally and theoretically with high percentage of recovery of $\mathrm{Pb}(99.9 \%), \mathrm{Cd}(100 \%)$, and $99 \%$ of As. The findings of the present study may help in recycling the extracted glass and trace elements instead of the proposed governmental plan by excavating and landfilling as hazardous wastes in special landfills.

Table 5 The XRF analysis of the extracted trace elements at the optimum reduction-melting operating conditions displayed in weight percentages

\begin{tabular}{ll}
\hline Element $(\mathrm{wt} \%)$ & $\begin{array}{l}\text { Extracted trace elements, } \\
\text { the present study }\end{array}$ \\
\hline $\mathrm{Cr}$ & 0.02 \\
$\mathrm{Mn}$ & 0.03 \\
$\mathrm{Cu}$ & 2.19 \\
$\mathrm{Zn}$ & 0.14 \\
$\mathrm{As}$ & 4.83 \\
$\mathrm{Cd}$ & 0.12 \\
$\mathrm{Sb}$ & 0.94 \\
$\mathrm{Ba}$ & 0.15 \\
$\mathrm{~Pb}$ & 91.58 \\
\hline
\end{tabular}


Acknowledgments The authors would like to thank Dr. Anna Augustsson (Department of Biology and Environmental Science at Linnaeus University) for milling the waste glass used during this study. We also acknowledge the support given by the Swedish Institute through the PHYTECO project.

Open Access This article is distributed under the terms of the Creative Commons Attribution 4.0 International License (http:// creativecommons.org/licenses/by/4.0/), which permits unrestricted use, distribution, and reproduction in any medium, provided you give appropriate credit to the original author(s) and the source, provide a link to the Creative Commons license, and indicate if changes were made.

\section{References}

Apostoli P, Giusti S, Bartoli D, Perico A, Bavazzano P, Alessio L (1998) Multiple exposure of arsenic, antimony and other elements in art glass manufacturing. Am J Ind Med 34:65-72

Avfall Sverige (2007) Uppdaterade bedömningsgrunder för förorenade massor. Report 2007:01. Avfall Sverige AB, Malmö, Sweden. (in Swedish)

Barbieri L, Lancellotti I, Ponzoni C (2014) Rapid screening of different chelating agents in the lead extraction from cathode ray tube (CRT) funnel glass. Environ Sci Pollut Res 21:13230-13236

Brahmapurkar K, Lanjewar A, Zodpey S, Shrote V, Khan Q, Khakse G, Sinha T, Giri V, Shrivastava P, Chauhan V (2013) Morbidities in the glass factory workers of central India. J Dent Med Sci 7:29-33

BREF (2009) Glass BREF, Integrated Pollution Prevention and Control - draft reference document on best available techniques in the glass manufacturing industry, Institute for Prospective Technological Studies, Joint Research Centre, European Commission, Seville, July 2009, ftp://ftp.jrc.es/pub/eippcb/doc/ gls_d2_07-2009.pdf

Bursi E, Ponzoni C, Lancellotti I, Vassura I, Ferroni L, Barbieri L (2015) Cathode ray tube (CRT) lead glass: lead leaching study after a chelating agent treatment. Environ Eng Manag J 14:1503-1509

Chen M, Zhan F, Zhu J (2009) Lead recovery and the feasibility of foam glass production from funnel glass of dismantled cathode ray tube through pyrovacuum process. J Hazard Mater 161:1109-1113

Elert M, Höglund L (2012) Huvudstudie Pukebergs Glasbruk. Kemakta AR 2012-07 rapport (in Swedish)

European Union (2003) Council Decision of 19 December 2002 establishing criteria and procedures for acceptance of waste at landfills pursuant to Article 16 and Annex II to Directive 1999/31/EC (2003/33/EC). Off J Eur Communities 16.1:L 11/27-L 11/49

Grause G, Takahashi K, Kameda T, Yoshioka T (2014) Lead removal from cathode ray tube glass by the action of calcium hydroxide and poly vinyl chloride. Thermochim Acta 596:49-55

Green D, Perry R (2007) Perry's chemical engineers' handbook, 8th edn. McGraw-Hill, New York ISBN:978-0-07-142294-9

Guo H, Gong Y, Gao S (2010) Preparation of high strength foam glass ceramics from waste cathode ray tube. Mater Lett 64:997-999

Höglund LO, Fanger G och Yesilova H (2007) SlutrapportGlasbruksprojektet 2006-2007, Länsstyrelserna i Kalmar och Kronobergs län, Kemakta Konsult AB, 2007-12-10 (in Swedish)

Hynes M, Forde S, Jonson B (2004) Element migration from glass compositions containing no added lead. Sci Total Environ 319:39-52

Jani Y, Hogland W (2014) Waste glass in the production of cement and concrete-a review. J Environ Chem Eng 2:1767-1775

Kalmar County Administrative Board (2016) Prioriteringslista över förorenade områden i Kalmar län (http://www.lansstyrelsen.se/
Kalmar/sv/miljo-och-klimat/verksamheter-med-miljopaverkan/ebh/ prioriteringslistan-lanets-mest-fororenade-omraden/Pages/default. aspx) (2016). Assessed Jan 2017. (in Swedish)

Kritikaki A, Zaharaki D, Komnitsas K (2016) Valorization of industrial waste for the production of glass ceramics. Waste Biomass Valoriz 7:885-898

Li Z, Yuan W, Ding S, Chen Y, Li J (2012) A study on PbO in CRT funnel glass at high temperature condition. Int J Environ Technol Manag 15:16-27

Mear F, Yot P, Cambon M, Ribes M (2006) The characterization of waste cathode ray tube glass. Waste Manag 26:1468-1476

Mingfei X, Yaping W, Jun L, Hua X (2016) Lead recovery and glass microspheres synthesis from waste CRT funnel glasses through carbon thermal reduction enhanced acid leaching process. J Hazard Mater 305:51-58

Okada T (2015) Lead extraction from cathode ray tube funnel glass melted under different oxidizing conditions. J Hazard Mater 292: 188-196

Okada T, Inano H, Hiroyoshi N (2012) Recovery and immobilization of lead in cathode ray tube funnel glass by a combination of reductive and oxidative melting processes. J SID 20:508-516

Okada T, Yonezawa S (2013) Energy efficient modification of reduction melting for lead recovery from cathode ray tube funnel glass. Waste Manag 33:1758-1763

Pant D, Singh P (2014) Pollution due to hazardous glass waste. Environ Sci Pollut Res 21:2414-2436

Pirastu R, Bartoli D, Battista G, De Santis M, Laia T, Orsi D, Tarchi M, Valiani M (1998) Cancer mortality of art glass workers in Tuscany, Italy. Scand J Work Environ Health 24(5):386-391

Rossini P, Matteucci G, Guerzoni S (2010) Atmospheric fall-out of metals around the Murano glass-making district (Venice, Italy). Environ Sci Pollut Res 17:40-28

Rousseau M, Parent M, Nadon L, Latreille B, Siemiatycki J (2007) Occupational exposure to lead compounds and risk of cancer among men: a population-based case control study. Am J Epidemiol 166: 1005-1014

SEPA (Swedish Environmental Protection Agency) (2016) De flesta förorenade områdena är kända (in Swedish). http://www. utslappshandel.se/Sa-mar-miljon/Mark/Fororenade-omraden/. Accessed Jan 2017

Shelby J (2005) Introduction to glass science and technology, 2nd edn. the Royal Society of Chemistry, UK

Singh N, Li J, Zeng X (2016) An innovative method for the extraction of metal from waste cathode ray tubes through a mechanochemical process using 2-[bis(carboxymethyl)amino] acetic acid reagent. ASC Sustain Chem Eng 4:4704-4709

Sripaiboonkij P, Sripaiboonkij N, Phanprasit W, Jaakkola M (2009) Respiratory and skin health among glass microfiber production workers: a cross-sectional study. Environ Health 36:1-10

Varun M, D'Souza R, Pratas J, Paul M (2012) Metal contamination of soil and plants associated with glass industry in North Central India: prospects of phytoremediation. Environ Sci Pollut Res 19:269-281

Vogel W (1994) Glass chemistry, 2nd edn. Springer-Verlag, Berlin

Xing M, Zhang F (2011) Nano-lead particle synthesis from waste cathode ray-tube funnel glass. J Hazard Mater 194:407-413

Zhang C, Wang J, Bai J, Guan J, Wu W, Guo C (2013) Recovering lead from cathode ray tube funnel glass by mechano-chemical extraction in alkaline solution. Waste Manag Res 31:759-763

Zhang L, Xu Z (2016) A review of current progress of recycling technologies for metals from waste electrical and electronic equipment. J Clean Prod 127:19-36 